
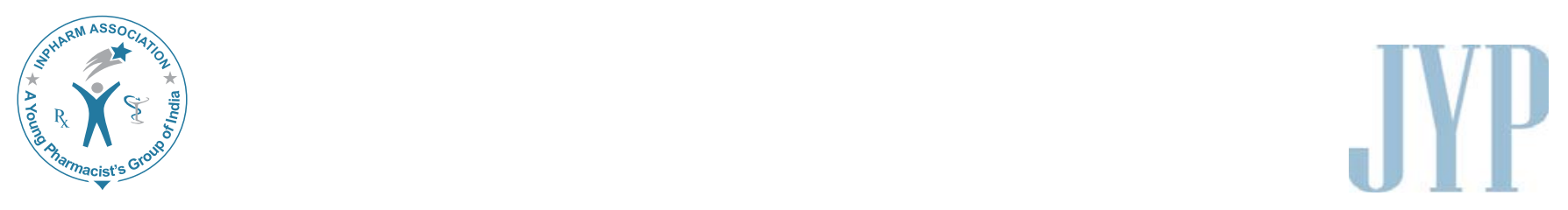

\title{
Patient-physician Communication Barrier: A Pilot Study Evaluating Patient Experiences
}

\author{
Khan TM, Hassali MA ${ }^{1}$, Al-Haddad MSM${ }^{1}$ \\ Department of Pharmacy Practice, College of Clinical Pharmacy, King Faisal University, Al-Ahsa 31982, \\ Kingdom of Saudi Arabia, ${ }^{1}$ Discipline of Social and Administrative Pharmacy, School of Pharmaceutical \\ Sciences, University Sains Malaysia 11800, Pulau Penang, Malaysia
}

Address for correspondence: Dr. Tahir Mehmood Khan; E-mail:tahir.pks@gmail.com

\begin{abstract}
This study aims to identify the patient-physician communication barriers in the primary healthcare setting in Pulau Penang, Malaysia. A cross-sectional study was designed to attain the objectives of the study. A self-developed 17-item study tool was used to explore respondent's perception about the barriers they have faced while communicating with physician. The reliability scale was applied and internal consistency of the study tool was estimated on the basis of Cronbach's alpha $(\alpha=0.58)$. The data analysis was conducted using statistical package for social sciences students SPSS $13^{\circledR}$. Chi Square test was used to test the difference between proportions. A total of $n=69$ patients responded to this survey. A higher participation was seen by the male respondents, 39 $(56.5 \%)$. About $52(76.5 \%)$ of the respondents were satisfied with the information provided by the physician. In an effort to identify the patient-physician barriers, a poor understanding among the patients and physician was revealed. $16(23.5 \%)$ respondents disclosed lack of satisfaction from the information provided to them. Overall, it is seen that lack of physician-patient understanding was the main reason that result hindrance in the affective communication. Moreover, there is a possibility that a low level of health literacy among the patients and inability of the physician to affectively listen to patients may be the other factors that result in a deficient communication.
\end{abstract}

Key words: Barriers, Malaysia, patient-physician communication

\section{INTRODUCTION}

Affective patient-physician communication is vital part in clinical practice. ${ }^{[1]}$ In the patient-physician context, the approaches physician adopts to communicate with patient

\begin{tabular}{|c|l|}
\hline \multicolumn{2}{|c|}{ Access this article online } \\
\hline Quick Response Code: & \multirow{2}{*}{ Website: } \\
\cline { 1 - 1 } & www.jyoungpharm.in \\
& \\
\hline
\end{tabular}

matters a lot. ${ }^{[1]}$ The patient-physician communication not only involve the guidance/information regarding prescription, but it is actually a set of knowledge sharing that focusing on the knowledge about the disease, risk factors/causes, guidance about the affective help seeking, and information about the drug regimens. ${ }^{[2,3]}$ It is found that those patients capable of understanding doctors are more apt to concede health problems, understand their treatment options, modify their behavior accordingly, and follow their medication schedules. ${ }^{[2,3]}$ In addition, it is noticed that a successful patient-physician communication can improve a patient's health; an observable response to the placebo during clinical trials is the result of a successful 
communication session. ${ }^{[2,3]}$ With amendments in citizenship and immigration laws, the unicultural societies are diversified and globally the multicultural/ethnic societies are originated. This diversification in cultures has made it quite difficult to define the true essence of the affective communication. ${ }^{[1,4]}$ Due to this diversification, the social/cultural and linguistic differences do affect the patient-physician communication. Moreover, a lack of longitudinal relationship between patient and physician (continuity of care) ${ }^{[1,5]}$ disagreement between the patient and physician on the problem or need and its management; ${ }^{[1,6]}$ patients' trust in their physician to act in their best interest; and finally, the physician's capabilities to enable the patient toward effective self-care (patient enablement ${ }^{[]]}$can be the other possible reasons for an ineffective communication. However, it is seen that the health service and preventive care has significantly improved where patient and physician have a long-term relation. ${ }^{[5,8]}$ This is because, the physicians have a good understanding about the psychosocial aspects of the patients and the patients feel more confident while sharing the problem and listening physician views. ${ }^{[9,10]}$ Keeping in view the worth of affective communication, $65 \%$ of medical institutions have taken the initiative to include communication skill as an essential subject in the curriculum. ${ }^{[1]}$ The main aim of these courses is to develop effective communication skills among the future doctor, so that they can perform an affective session with patient. That is why training in patientphysician communication is now objectively evaluated as a core competency. ${ }^{[12,13]}$ But again, due to the increase in the cultural diversity worldwide, ${ }^{[1,4]}$ these efforts to improve and assess communication skills of healthcare professional are timely, as the barriers to effective communication between patients and physicians are growing. ${ }^{[14]}$

\section{Patient-physician communication in Malaysia}

Malaysia is a multicultural country that mainly comprises of three ethnic groups; Malay, Indians, and Chinese. In addition, foreigners from different Asian and Arab region are the other groups residing in Malaysia. Malay, Tamil, Hindi, Punjabi, and Chinese are the commonly spoken languages by the natives. This diversity of language and culture would be factors that result in some barrier during the patientphysician communication. ${ }^{[15,16]}$ Furthermore, in this 15 -to 20-minute session, the physicians should choose appropriate words, tones, and facial expressions to result in an affective counseling session. So far in Malaysia, there is no previous effort that has evaluated the communication barriers in primary care setting among patient andphysician. Keeping this in view, this study will identify the communication barriers among patient and physician.

\section{METHODOLOGY}

In order to explore the patient-physician communication barriers, a cross-sectional study was designed using a nonexperimental questionnaire-based method.

Study population

Penang is one of 13 states in Malaysia. It is comprised of two parts, i.e., Penang Island and mainland. This study was conducted in Penang Island. Three main ethnic groups resides in Penang Island, i.e., Malay, Chinese, and Indians.

\section{Sampling method}

A representative sample was chosen from state of Penang. The target population for our study was the patients attending the private clinics. To ease the process of sampling, Penang Island was divided into four subpopulations, i.e., Balik Pulau, Georgetown, Gurney, and Gelugor populations. Another reason for this division was to approach the representative sample that is residing in different areas of Penang. In order to approach the potential respondents, only one clinic was selected from these four areas. A total of 25 respondents were approached from every clinic. A convenient sampling method was adopted. Those willing to participate for the study were welcomed.

\section{Contents of study tool}

A self-developed 17-item study tool was used to explore respondent's perception about the barriers they have faced while communicating with physician. The study tool main comprised of four sections. Section one covers the demographic information of the patients, i.e., race, age, gender, marital status, level of education, and religion. Section two comprises of two questions that explores about the language used by the physicians and how you will rate the information provided to you by the physician. Four options, i.e., very good, good, intermediate, and poor, were given to the patients to rank the quality of information provided by the physician. Section three was the most important part of the questionnaire. This section identifies the barriers that lay hindrance in patient-physician communication. A total of six questions were part of this section. However, section four comprises of three questions that highlight the patient's level of agreement with the recommendation to improve the patient-physician communication. The content validity of the tool was done by the lectures at the department of pharmacy, Island College of technology. However, the face validity of the tool was done by the 20 patients attending Hospital Balik Pulau. Keeping in view the responses, the reliability scale 
was applied and internal consistency of the study tool was estimated on the basis of Cronbach's alpha $(\alpha=0.58)$.

\section{Ethical considerations}

The study protocol was approved by the research and ethics committee, chaired by the dean department of pharmacy, Island college of Technology. A permission from the practicing physician to conduct this study was also taken. Furthermore, a written consent was taken from the respondents and it was assured that all the information will be kept confidential.

\section{Data analysis}

The data analysis was conducted using statistical package for social sciences students SPSS $13^{\circledR}$. Chi Square test was used to test the difference between proportions with the confidence interval of $95 \%$. Alpha value less than 0.05 was considered significant.

\section{RESULTS}

A total of $N=100$ patients were approached for their potential participation in this study. Of these, $n=69$ patients responded to this survey. A higher participation was seen by the male respondents, 39 (56.5\%). Details about the demographic of respondents are mentioned in Table 1.

Language adopted by the physician

Patient evaluations in this regard revealed that physician were more willing to communicate with their patient in Malay language, 37 (53.62\%). Other languages used by the physician for patient communication were Tamil, $12(17.39 \%)$, followed by Mandarin, 9 (13.04\%), and English, 8 (11.59\%).

Patient level of satisfaction from the information provided by the physician

Patient satisfaction was one of the essential part of this study; about $52(76.5 \%)$ of the respondents were satisfied with the information provided by the physician. However, $16(23.5 \%)$ respondents disclosed lack of satisfaction from the information provided to them [Table 2].

Respondents' views about the communication barriers and recommendations to improve the patientphysician communication barriers

In an effort to identify the patient-physician barriers, a poor understanding among the patients and physician was revealed. Nearly $53(76.8 \%)$ reported the good attitude of
Table 1: Demographic data of respondents $(N=69)$

\begin{tabular}{|c|c|c|}
\hline Characteristics & $N(69)$ & $\%$ \\
\hline \multicolumn{3}{|l|}{ Gender } \\
\hline Male & 39 & 56.5 \\
\hline Female & 30 & 43.5 \\
\hline \multicolumn{3}{|l|}{ Race } \\
\hline Malay & 35 & 50.7 \\
\hline Chinese & 20 & 29.0 \\
\hline Indians & 14 & 20.3 \\
\hline \multicolumn{3}{|l|}{ Age } \\
\hline $18-25$ & 28 & 40.6 \\
\hline $26-30$ & 8 & 11.6 \\
\hline $31-40$ & 7 & 10.1 \\
\hline $41-50$ & 9 & 13.0 \\
\hline 51 and over & 17 & 24.6 \\
\hline \multicolumn{3}{|l|}{ Marital status } \\
\hline Married & 31 & 44.9 \\
\hline Widowed & 1 & 1.4 \\
\hline Divorced & 2 & 2.9 \\
\hline Separated & 2 & 2.9 \\
\hline Single & 33 & 47.8 \\
\hline \multicolumn{3}{|l|}{ Religious affiliation } \\
\hline Islam & 40 & 56.0 \\
\hline Hindu & 6 & 8.7 \\
\hline Christian & 7 & 10.1 \\
\hline Buddhist & 13 & 18.8 \\
\hline Others & 3 & 4.3 \\
\hline \multicolumn{3}{|l|}{ Level of education } \\
\hline PMR & 3 & 4.3 \\
\hline SPM & 18 & 26.1 \\
\hline Under graduate & 32 & 46.4 \\
\hline Diploma & 16 & 23.2 \\
\hline \multicolumn{3}{|c|}{ Language used by the physician } \\
\hline Malay & 37 & 54.4 \\
\hline Mandarin & 9 & 13.2 \\
\hline Tamil & 2 & 2.9 \\
\hline English & 12 & 17.6 \\
\hline Other & 8 & 11.8 \\
\hline
\end{tabular}

PMR - Penilaian menengah rendah (Secondary school education certificate), SPM Sijil pelajaran malaysia (Malaysian certificate of education examination)

physician. However, few reported a lack of understanding with the information provided by the physician [Table 3].

In response to the question, how to improve the patientphysician communication, nearly all mentioned that physician should have the capabilities to speak the local languages (i.e., Malay, Tamil, Chinese). It is the responsibility of the medical colleges to improve the language skills of the physicians. About $60(87.0 \%)$ mentioned that it will be a better option if the physicians explain the information regarding disease to the patient. Moreover, nearly 58 (84.5\%) mentioned that physician should behave with patient in a polite manner; earning money is not the only thing, physician must understand their responsibilities toward patients. Detailed respondents' view about the interventions to improve the communication between patient and physician are shown in Table 4.

\section{DISCUSSION}

Patients approaching a physician always expect good and 
Table 2: Respondents views about the quality of information provided by the physician $(N=69)$

\begin{tabular}{|c|c|c|c|c|c|c|}
\hline Characteristics & $\begin{array}{l}\text { Very } \\
\text { good }\end{array}$ & Good & Intermediate & Poor & $\chi^{2}$ & $\begin{array}{c}P \\
\text { value }\end{array}$ \\
\hline \multicolumn{7}{|l|}{ Gender } \\
\hline Male & 5 & 20 & 13 & - & \multirow[t]{2}{*}{2.709} & \multirow[t]{2}{*}{0.420} \\
\hline Female & 5 & 11 & 13 & 1 & & \\
\hline \multicolumn{7}{|l|}{ Race } \\
\hline Malay & 5 & 18 & 12 & - & \multirow[t]{3}{*}{11.858} & \multirow[t]{3}{*}{0.419} \\
\hline Chinese & 2 & 8 & 10 & - & & \\
\hline Indians & 3 & 5 & 4 & 1 & & \\
\hline \multicolumn{7}{|l|}{ Age } \\
\hline $18-25$ & 1 & 11 & 16 & - & \multirow[t]{5}{*}{22.474} & \multirow[t]{5}{*}{$0.022 *$} \\
\hline $26-30$ & 2 & 4 & 1 & 1 & & \\
\hline $31-40$ & 1 & 2 & 4 & - & & \\
\hline $41-50$ & 3 & 3 & 2 & - & & \\
\hline 51 and over & 3 & 11 & 3 & - & & \\
\hline \multicolumn{7}{|l|}{ Marital status } \\
\hline Married & 7 & 20 & 13 & - & \multirow[t]{5}{*}{11.702} & \multirow[t]{5}{*}{0.138} \\
\hline Widowed & - & 2 & 2 & 1 & & \\
\hline Divorced & 3 & 2 & 2 & - & & \\
\hline Separated & - & 6 & 7 & - & & \\
\hline Single & - & 1 & 2 & - & & \\
\hline \multicolumn{7}{|l|}{ Religion } \\
\hline Islam & 7 & 20 & 13 & - & \multirow[t]{5}{*}{22.404} & \multirow[t]{5}{*}{$0.033^{*}$} \\
\hline Hindu & - & 2 & 2 & 1 & & \\
\hline Christian & 3 & 2 & 2 & - & & \\
\hline Buddhist & - & 6 & 7 & - & & \\
\hline Others & - & 1 & 2 & - & & \\
\hline \multicolumn{7}{|l|}{ Level of education } \\
\hline $\begin{array}{l}\text { PMR (Primary } \\
\text { education) }\end{array}$ & - & 2 & 1 & - & \multirow[t]{4}{*}{8.314} & \multirow[t]{4}{*}{0.463} \\
\hline $\begin{array}{l}\text { SPM (Secondary } \\
\text { education) }\end{array}$ & 5 & 6 & 6 & 1 & & \\
\hline Under graduate & 2 & 16 & 13 & - & & \\
\hline Diploma & 3 & 7 & 6 & - & & \\
\hline
\end{tabular}

Fischer Exact test, *Significant $P=<0.05$

Table 3: Barriers faced by patient during discussion with physician $(N=69)$

\begin{tabular}{|c|c|c|c|c|}
\hline & Race & $\begin{array}{c}\text { Agree } \\
(\%)\end{array}$ & $\begin{array}{c}\text { Disagree } \\
(\%)\end{array}$ & $\begin{array}{l}\text { Undisclosed } \\
(\%)\end{array}$ \\
\hline \multirow{3}{*}{$\begin{array}{l}\text { He was unable to } \\
\text { understand what I am } \\
\text { trying to say }\end{array}$} & Malay & 11 (15.9) & $21(30.4)$ & $3(4.3)$ \\
\hline & Chinese & $5(7.2)$ & $10(14.5)$ & $5(7.2)$ \\
\hline & Indian & 7 (10.1) & $6(8.7)$ & - \\
\hline \multirow{3}{*}{$\begin{array}{l}\text { I cannot understand } \\
\text { what he says because } \\
\text { he was speaks too fast }\end{array}$} & Malay & 11 (15.9) & $22(31.9)$ & $2(2.9)$ \\
\hline & Chinese & $3(4.3)$ & 15 (21.7) & $2(2.9)$ \\
\hline & Indian & $2(2.9)$ & $9(13.0)$ & $2(2.9)$ \\
\hline \multirow{3}{*}{$\begin{array}{l}\text { The attitude of } \\
\text { physician was good }\end{array}$} & Malay & $28(40.6)$ & - & 7 (10.1) \\
\hline & Chinese & 17 (24.6) & - & $3(4.3)$ \\
\hline & Indian & 8 (11.6) & $2(2.9)$ & $3(4.3)$ \\
\hline \multirow{3}{*}{$\begin{array}{l}\text { Have you ever been } \\
\text { scolded by physician } \\
\text { during treatment/ } \\
\text { counseling/discussion }\end{array}$} & Malay & $4(5.8)$ & $29(42.0)$ & $2(2.9)$ \\
\hline & Chinese & $2(2.9)$ & $17(24.6)$ & $1(1.4)$ \\
\hline & Indian & $2(2.9)$ & $10(14.5)$ & $1(1.4)$ \\
\hline \multirow{3}{*}{$\begin{array}{l}\text { I do not know what } \\
\text { doctor was talking about }\end{array}$} & Malay & $9(13.0)$ & $20(29.0)$ & $6(8.7)$ \\
\hline & Chinese & $3(4.3)$ & 15 (21.7) & $2(2.9)$ \\
\hline & Indian & $2(2.9)$ & $9(13.0)$ & $2(2.9)$ \\
\hline \multirow{3}{*}{$\begin{array}{l}\text { Doctor was not listening } \\
\text { to me carefully and was } \\
\text { explaining his personal } \\
\text { opinio }\end{array}$} & Malay & $4(5.8)$ & $29(42.0)$ & $2(2.9)$ \\
\hline & Chinese & $4(5.8)$ & 15 (21.7) & $1(1.4)$ \\
\hline & Indian & $3(4.3)$ & $7(10.1)$ & $3(4.3)$ \\
\hline
\end{tabular}

detailed information regarding his medical condition, complications, therapy, and adverse events associated with
Table 4: Patients response to the recommendations that may improve patient physician barriers $(N=69)$

\begin{tabular}{|c|c|c|c|c|}
\hline & Race & $\begin{array}{c}\text { Agree } \\
(\%)\end{array}$ & $\begin{array}{c}\text { Disagree } \\
(\%)\end{array}$ & $\begin{array}{c}\text { Neutral } \\
(\%)\end{array}$ \\
\hline $\begin{array}{l}\text { Physician should have ability } \\
\text { to communicate in various } \\
\text { languages spoken in Malaysia } \\
\text { [i.e., Malay, Tamil, Chinese]. }\end{array}$ & $\begin{array}{l}\text { Malay } \\
\text { Chinese } \\
\text { Indian }\end{array}$ & $\begin{array}{l}34(56.6) \\
19(31.7) \\
12(20.0)\end{array}$ & $\begin{array}{c}1(1.6) \\
0 \\
1(1.6)\end{array}$ & $\begin{array}{c}0 \\
1(1.6) \\
0\end{array}$ \\
\hline $\begin{array}{l}\text { Physician must explain } \\
\text { information about disease } \\
\text { and medicine to their } \\
\text { patients in details }\end{array}$ & $\begin{array}{l}\text { Malay } \\
\text { Chinese } \\
\text { Indian }\end{array}$ & $\begin{array}{l}35(58.3) \\
18(30.0) \\
12(20.0)\end{array}$ & $\begin{array}{c}0 \\
0 \\
1(1.6)\end{array}$ & $\begin{array}{c}0 \\
2(3.3) \\
0\end{array}$ \\
\hline $\begin{array}{l}\text { Physician must know about } \\
\text { their responsibilities toward } \\
\text { their patients }\end{array}$ & $\begin{array}{l}\text { Malay } \\
\text { Chinese } \\
\text { Indian }\end{array}$ & $\begin{array}{l}35(58.3) \\
19(31.7) \\
12(20.0)\end{array}$ & $\begin{array}{c}0 \\
0 \\
1(1.6)\end{array}$ & $\begin{array}{c}0 \\
1(1.6) \\
0\end{array}$ \\
\hline
\end{tabular}

therapeutic regimes. ${ }^{[17]}$ The level of communication among the patient and physician decide the effectiveness of the session. Communication session between the patient and physician is not perfect always, it often face barriers that result flaws in the patient-physician communication. ${ }^{[17]}$ In general, language used by the physician during the communication session, cultural gaps, physician attitude toward patients, and the complex information are the commonly seen barriers during a patient-physician communication session. ${ }^{[17]}$

In current study, majority $(38.2 \%)$ of the respondents has rated overall communication as intermediate. Further evaluation revealed [Table 2] that the Malay Muslim patients, especially those aged 18 to 25 years, were found to report intermediate level of satisfaction with the information provided by the physician. The possibilities for this response are needed to be exploring in the future studies. However, one can assume several factors responsible for the lack of satisfaction. ${ }^{[1,12,14]}$ One of the most important among these is the low level of health literacy, which limits the ability of the patient to affectively explain their views about the disease they are suffering from. However, there is a possibility that may be there were some real gaps in the patient-physician communication which are needed to be identified in the future studies. ${ }^{[14]}$

In addition, one cannot ignore the difference in the communication style as it varies from physician to physician $^{[1]}$ and this is perhaps one of the another limitation of this study, because it was a pilot project and a limited sample was taken which limit the researcher ability to identify the variance in the physician communication style. Future studies should focus on this issue so that the communication variance in the Malaysian physician is evaluated, which will help the medical education provider to design some communication-oriented intervention to standardize the communication style of the future medical graduates. Keeping in view this variation in communication styles, the Accreditation Council for 
Graduate Medical Education recommends that physicians should have the following five key communication skills: (1) must listen carefully to the patient when he is describing about the condition; (2) obtain information using effective and simple questioning skills; (3) explain and provide information using effective explanatory skills; (4) counseling and educating patients; and (5) making informed decisions based on patient information and preference. ${ }^{[12,18]}$ Particularly discussing these five elements of the communication, the patient education and counseling is perhaps one of the neglected areas in the private medical practice in Malaysia. The reason for this is the unavailability of the pharmacist on the dispensing window. In Malaysia, like most of the Asian countries, physicians are allowed to operate a small dispensary with their clinic, where they are allowed to dispense the prescription for their patients. Unfortunately, the person who dispenses the medicine is not a pharmacist and this can be another factor that result a defected communication. Patient understanding and level of satisfaction may be better if a pharmacist brief the patient about the disease and counsel the patient about the safe use of drug. A randomized controlled trial will be an effective way to compare the effectiveness of the counseling session conducted by physician and a pharmacist.

Furthermore, to identify the communication barriers, it was revealed that $14(20.3 \%)$ disclosed that they were unable to understand what physician is talking about. Two possibilities are there to further elaborate this issue; one the lack of ability of the patient to understand what physician is saying, which may be due to the low-level health literacy among the patients, and second possibility is the incompetency of the physician to affectively communicate the required information to the patient. The insufficiency on the part of patient can be avoided; however, physician deficiencies cannot be ignored because it has a main impact on the treatment outcome. Travaline et al. (2005) have stressed on the need that a physician must evaluate his patient's knowledge and understanding about his/her current condition. ${ }^{[19]}$ In this way, it is convenient for the physician to decide what he should provide to the patient and what he wants to know about his particular condition. ${ }^{[20,21]}$ Furthermore, for a fruitful Patient- physician communication session it is strongly recommended that the physician should develop the skill of empathy, to help them recognize the indirectly expressed emotions of their patients, ${ }^{[21]}$ and all these will be more effective if the physician make all the communication by selecting the simple terminologies that are easy to understand by the patient. ${ }^{[19]}$

\section{LIMITATIONS}

This was a pilot study and a small sample size can be one of the possible limitations of this study. However, a systematic sampling method was adopted to decrease the sampling biases. As the identification of patient-physician communication barrier is a vast issue, there is big room for future studies in Malaysia. These findings will act as a base for the future methodologically strong studies that explores in detail the issue / barriers affecting the patient-physician communication in Malaysian health care setting.

\section{WHAT THIS STUDY ADDS}

This was the first effort to identify the patient-physician communication barriers. Though this study has some sample limitation, one cannot ignore the gaps highlighted by this study in the patient-physician communication session. The findings of the current study draw the attention of the policy makers and the public health department to take some positive steps to incorporate the role of pharmacist in private practice. By taking this initiative, it can be assumed that the deficiencies in the patient-physician communication session will be compensated up to some extent through the patient counseling by the pharmacist. However, certain aspects on the part of physician cannot be ignored, which can be resolved by revision/modification of the policies regarding the private medical practice in Malaysia.

\section{CONCLUSION}

Lack of physician-patient understanding was the main reason that results in hindrance in the affective communication. In addition, the possible reasons for the communication barriers may be the low level of health literacy among the patients and inability of the physician to affectively listen to patients' views and describe the detailed information about the drug and disease.

\section{REFERENCES}

1. Travaline JM, Ruchinskas R, D’Alonzo GE Jr. Patient-physician communication: Why and how. J Am Osteopath Assoc 2005;105:13-8.

2. Stewart MA. Effective physician-patient communication and health outcomes: A review. CMAJ 1995;15:1423-33.

3. Bogardus ST Jr, Holmboe E, Jekel JF. Perils, pitfalls, and possibilities in talking about medical risk. JAMA 1999;281:1037-41.

4. Balint J, Shelton W. Regaining the initiative. Forging a new model of the patient-physician relationship. JAMA 1996;275:887-91.

5. Christakis DA, Mell L, Wright JA, Davis R, Connell FA. The association between greater continuity of care and timely measles-mumpsrubella vaccination. Am J Public Health 2000;90:962-5. 
6. Vedsted P, Mainz J, Lauritzen T, Olesen F. Patient and GP agreement on aspects of general practice care. Fam Pract 2002;19:339-43.

7. Howie JG, Heaney DJ, Maxwell M, Walker JJ. Quality at general practice consultations: Cross sectional survey. BMJ 1999;319:738-43.

8. Gill J, Mainous AI. The role of provider continuity in preventing hospitalizations. Arch Fam Med 1998;7:352-7.

9. Hjortdahl P, Laerum E. Continuity of care in general practice: Effect on patient satisfaction. BMJ 1992;304:1287-90.

10. Saultz JW. Defining and measuring interpersonal continuity of care. Ann Fam Med 2003;1:134-43.

11. Kalet A, Pugnaire MP, Cole-Kelly K, Janicik R, Ferrara E, Schwartz MD, et al. Teaching communication in clinical clerkships: Models from the macy initiative in health communications. Acad Med 2004;79:511-20.

12. Duffy FD, Gordon GH, Whelan G, Cole-Kelly K, Frankel R, Buffone N, et al. Assessing competence in communication and interpersonal skills: The Kalamazoo II report. Acad Med 2004;79:495-507.

13. Makoul G. MSJAMA. Communication skills education in medical school and beyond. JAMA 2003;289:93.

14. Mechanic D, McAlpine DD, Rosenthal M. Are patients' office visits with physicians getting shorter? N Engl J Med 2001;344:198-204.

15. Betancourt JR, Green AR, Carrillo JE, Ananeh-Firempong O $2^{\text {nd. }}$ Defining cultural competence: A practical framework for addressing racial/ethnic disparities in health and health care. Public health rep 2003;118:293-302

16. Kundhal KK, Kundhal PS. MS Cultural diversity: An evolving challenge to physician-patient communication. JAMA 2003;289:94.

17. Mirza A. Kashmiri language and physician-patient communication barrier. JK Pract 2005;12:111-2.

18. Accreditation Council for Graduate Medical Education. Toolbox for the evaluation of competence. Available from: http://www.acgme.org. [last accessed on 2004 Jul 7].

19. Travaline JM, Ruchinskas R, D’Alonzo GE Jr. Patient-Physician Communication: Why and How. J Am Osteopath Assoc 2005;105:13-8.

20. Miller SM. The interacting effects of coping styles and situational variables in gynecologic settings: Implications for research and treatment. J Psychosom Obstet Gynaecol 1988;9:23-34.

21. Suchman AL, Markakis K, Beckman HB, Frankel R. A model of empathic communication in the medical interview. JAMA 1997;277:678-82.

How to cite this article: Khan TM, Hassali MA, Al-Haddad MSM. Patientphysician communication barrier: A pilot study evaluating patient experiences. $J$ Young Pharmacists 2011;3:250-5.

Source of Support: Nil, Conflict of Interest: None declared.

\section{Staying in touch with the journal}

1) Table of Contents (TOC) email alert Receive an email alert containing the TOC when a new complete issue of the journal is made available online. To register for TOC alerts go to http://www.jyoungpharm.in/signup.asp.

\section{2) RSS feeds}

Really Simple Syndication (RSS) helps you to get alerts on new publication right on your desktop without going to the journal's website. You need a software (e.g. RSSReader, Feed Demon, FeedReader, My Yahoo!, NewsGator and NewzCrawler) to get advantage of this tool. RSS feeds can also be read through FireFox or Microsoft Outlook 2007. Once any of these small (and mostly free) software is installed, add http://www.jyoungpharm.in/rssfeed.asp as one of the feeds. 